\title{
Identification of Yeasts Isolated from the Pulp in Nature and the Production of Homemade "Umbu" Wine
}

\author{
Dângelly Lins Figuerôa Martins de Melo*, Flávia Cristiana Santos, Antônio Marcio \\ Barbosa Junior, Patrícia Oliveira Santos, Marcelo Augusto Gutiérrez Carnelossi and Rita \\ de Cássia Trindade \\ ${ }^{1}$ Laboratório de Microbiologia Aplicada; Departamento de Morfologia; Universidade Federal de Sergipe; \\ LMA/DMO/UFS; Av. Marechal Rondon, s/n; Jardim Rosa Elze; 49.100-000; dangelly@ufs.br; São Cristóvão - SE - \\ Brasil.
}

\begin{abstract}
The goal of this work was to select strains of fermentation yeasts and test them in a small-scale production of “ umbu" fruit wine. The fruits were collected in N. Sra da Gloria city in Sergipe, Brazil. The fruit pulp was diluted and aliquots were inoculated on YMA plates. The yeasts strains were submitted to fermentation using "umbu" fruit juice as substrate, exception with to those strains of species related to pathological processes. The yeasts tested produced a beverage characterized between dry to light due to its alcoholic content with very nice taste, translucent appearance, of green to light yellow color.
\end{abstract}

Key words: Spondias tuberosa, wine of fruit, non-saccharomyces

\section{INTRODUCTION}

The yeasts are microorganisms that belong to the Fungi due to the lack of photosynthesis absence of motion structures, presence of rigid cellular wall and nucleus membrane; however, they differ from filamentous fungi by showing themselves, predominantly under unicellular form. The majority is classified as ascomycetous and show themselves as spherical, oval or cylindrical cells, with cellular division through budding (Pelczar, 1980; Madigan et al., 2004). The distribution of yeasts "in natura" is done by insect vector and wind. The flowers and fruits are important habitats to their development due to the high concentration of simple sugars and low pH (Pelczar, 1980). Many authors have isolated yeasts with fermentative capacity from fruits, citric concentrates and other sugar substrates (Brannon; Pollit, 1935; Trindade et al., 2002).

Due to their high fermentative capacity, the yeasts are essential in the production of alcoholic beverages. Among them, Saccharomyces cerevisiae is universally employed in processes for the production of alcoholic beverages, especially wines. The term wine is only used for the fermentation of grapes, however, many other fruits can be used in the same process (Martins, 1998, Madigan et al., 2004, Dorneles et al., 2005), as well as other species of yeasts associated to these fruits (Trindade et al. 1999).

Among the fruits that have the potential for the production of beverages, the fruits of Spondias tuberosa present appropriate characteristics (sugar content, $\mathrm{pH}$, and others). Moreover, they are much appreciated both nature and as processed products

\footnotetext{
${ }^{*}$ Author for correspondence
} 
such as sweets, juices and popsicles. In this context, this work focused on the selection yeast strains from the fresh and frozen pulps of "umbu" for the production of homemade "umbu" wine.

\section{MATERIALS AND METHODS}

The fruits from the "umbu" tree were collected in Nossa Senhora da Glória/SE, Brazil. Thirty samples were collected aseptically in plastic bags and then processed in a blender $(10 \%$ sterile saline; $0.5 \mathrm{~g}$ of fruit samples). The isolation of the yeasts was done by inoculations of decimal dilutions of the samples in YM Agar plates $(0.3 \%$ extract of yeast, $0.5 \%$ peptone, $2 \%$ of glucose and $2 \%$ of agar), with $100 \mathrm{mg} / \mathrm{L}$ of chloramphenicol. The plates were incubated at $25^{\circ} \mathrm{C} \pm 3^{\circ} \mathrm{C}$ for $5-8$ days. After that, the selection and purification of the morph types was done. The isolated yeasts were identified according to Yarrow (1998), and Kurtzman and Fell (1998). After selecting and purifying, the isolates were stored on GYMP broth at $-80^{\circ} \mathrm{C}$. Among the isolated species that showed fast glucose fermentation profile at least one isolate was used in the test for production of homemade "umbu" wine. The test was performed using a protocol adapted from Trindade and colleagues (1999) according to the following steps: a) Preparation of "umbu" must: Brix was corrected to $20^{\circ}$, because the pulp is sugar poor. The must was sterilized by autoclave; b) Production of pre-inocullum: yeasts were grown on Sabouraud Agar for $24 \mathrm{~h}$ and then $15 \mathrm{ml}$ from the must was added until a visible gas production and a "Brix reduction; c) Production of "umbu" wine: pre-inocullum content was put in $500 \mathrm{ml}$ of corrected and sterilized must. The broth was homogenized and SST was verified every day until stabilization. The sensorial analysis was done according to Teixeira (1987), aiming the comparison of the wines produced by different species and selecting the best one. For this purpose, a quantitative test was conducted comparing different wines using a structured standardized questionnaire with the following items: appearance, aroma and taste, the evaluation varying within a Hedonic rating (from "I really hated it" = score 1 to "I really loved it" = score 9). The wine tasters were selected randomly, among students and staff from Universidade Federal de Sergipe. The experiment was set in a casual scheme with three repetitions. Analysis of variance (ANOVA) was performed and the average grades were submitted to Tukey's test at $5 \%$ of probability using the ASSISTAT program (Silva, 1996; Silva; Azevedo, 2002).

\section{RESULTS AND DISCUSSION}

Seventeen species were identified comprising 54 isolates (Table 1). These results corroborated with several authors, Brannon; Pollit (1935), Owama; Saunders, (1980); Furlaneto et al., (1982); Morais et al., (1995), Trindade et al., (1999); Trindade et al., (2002) that isolated yeasts from fruits. The genera Candida, Rhodotorula, Kluyveromyces, Pichia, Trichosporon, Kloeckera, Zygosaccharomyces have been isolated from natural food such as honey, fruit juices, milk and others, as well as from industrialized food (Cook, 1958; Jay, 1970; Ivo, 1982; Wiskiewski et al., 1988 in Magalhães; Queiroz, 1991).

Table 1- Frequency of occurrence of identified yeast species.

\begin{tabular}{lclc}
\hline \multicolumn{1}{c}{ Species (Ascomycetous) } & number of isolates & \multicolumn{1}{c}{ Species (Basidiomycetous) } & number of isolates \\
\hline Pichia membranifaciens & 2 & Cryptococcus flavus & 1 \\
Candida floricola-like & 1 & Cryptococcus humiculus & 1 \\
Candida geochares & 1 & Cryptococcus laurentii & 1 \\
Candida parapsilosis & 4 & Black yeast & 1 \\
Candida sergipensis & 13 & Trichosporon moniliforme-like & 1 \\
Candida sorbosivorans & 9 & & \\
Candida spandovensis & 11 & & \\
Candida tennuis-like & 1 & & \\
Candida valida & 3 & & \\
Kloeckera japonica & 1 & & $\mathbf{5 4}$ \\
Kluyveromyces marxianus & 1 & & \\
Issatchenkia occidentalis & 2 & & \\
TOTAL & & & \\
\hline
\end{tabular}


The prevalence of ascomycetous yeasts was in agreement with the results of Santos et al., (1996). These authors stated that the basidiomycetous yeasts were predominant in flowers and green fruits, and as the fruit ripened, the ascomycetics and black yeasts dominate. The species with higher occurrence (24\%) was the Candida sergipensis, described by Trindade and colleagues (2004). Considering that this yeast was isolated only from the frozen substrate, it could be inferred that its predominance was related to the selective pressure from the low temperatures that led to low competition.

Recent works have confirmed that Brazil has a great potential in diversity of yeast communities, which included Wickerhamiella australiensis, W. cacticola, W. occidentalis, C. drosophilae, C. lipophila, Starmerella gen. Nov. S.bombicola sp. Nov., Kodamaea anthophila, $K$. nitulidarum, $C$. restingae, C. batistae, C. hagleri, C. sergipensis, Saturnispora hagleri, C. riodocensis, C. cellae, C. bromeliacearum and C. ubatubensis, isolated from natural substrates such as flowers, vector insects and cactus (Rosa; Lachance, 1998; Rosa et al., 1999a,b; Trindade et al., 2004; Morais et al., 2005; Pimentel et al., 2005, Ruivo et al., 2005).

Out of the 54 yeasts isolated from the fruits of the "umbu" tree, 50 presented high-fermentative ability (gas production $\geq 50 \%$ Durhan tube after 24h). As emphasized by Hagler et al. (1995), some substrates in which yeasts are far from being the ideal for these microorganisms and the "umbu" pulp could be one of them, due to the low amount of sugar. However, the ability of the yeasts in using a wide range of organic compounds (Phaff, 1991) allowed the occupation of these niches and explained the expressive presence of the yeasts in the "umbu" pulp.

Table 2 presents the results of the homemade "umbu" wine production expressed as amount of alcohol, total soluble solids, total acidity, $\mathrm{pH}$ and the fermentation period.

Table 2 - Representation of the alcoholic content - AC $\left({ }^{\circ} \mathrm{GL}\right)$, total acidity - TAA (\% acetic acid), total soluble solids - TSS $\left({ }^{\circ}\right.$ Brix $)$, of the "umbu" wine produced by different yeast strains.

\begin{tabular}{|c|c|c|c|c|c|}
\hline Strain & Specie of yeast & TA $\left({ }^{\circ} \mathbf{G L}\right)$ & TSS $\left({ }^{\circ}\right.$ Brix $)$ & $\begin{array}{c}\text { TAA } \\
\text { (\% acetic } \\
\text { acid) }\end{array}$ & $\begin{array}{c}\text { Time of activity } \\
\text { (days)* }\end{array}$ \\
\hline R-101 & Candida sergipensis & $10 \mathrm{a}$ & 12.6 & 0.82 & 12 \\
\hline R-94 & Candida sergipensis & $8 \mathrm{c}$ & 16.0 & 0.97 & 16 \\
\hline $\mathrm{R}-03$ & Candida valida & $10 \mathrm{a}$ & 14.0 & 0.99 & 16 \\
\hline $\mathrm{R}-100$ & Candida sorbosivorans & $9 b$ & 15.8 & 0.94 & 14 \\
\hline $\mathrm{R}-133$ & Kluyveromyces marxianus & $9 b$ & 14.2 & 0.93 & 12 \\
\hline R-109 & Candida tennuis - like & $10 \mathrm{a}$ & 13.8 & 0.94 & 16 \\
\hline $\mathrm{R}-48$ & Kloeckera japonica & $8 c$ & 12.0 & 0.92 & 12 \\
\hline $\mathrm{R}-279$ & Candida geochares & $8 \mathrm{c}$ & 15.8 & 0.96 & 12 \\
\hline $\mathrm{R}-107$ & Candida floricola-like & $10 \mathrm{a}$ & 15.2 & 0.82 & 18 \\
\hline
\end{tabular}

Average followed by the same lower case letter in the column did not differ (Tukey's test; $\alpha=0.05$ )

The "umbu" wines produced by different yeast strains presented significant variations related to the amount of alcohol and consumption of available sugars (Table 2). The strains $(C$. spandovensis), R-03 (C. valida), R-109 (C. tennuis-like) and $\mathrm{R}-107$ (C. floricola-like) produced wines with the highest amount of alcohol (10\%GL). According to required time for stabilization of the fermentative process, strain $\mathrm{R}$ 101 was most efficient (Table 2).

As for the sensorial characteristics, the wines showed transparency, very nice taste, color between green and light yellow and could be classified as between dry to light. Tables 3 and 4 showed the results of sensorial analyses, which contained, respectively, the average scores and the percentage of acceptance and refusal of the "umbu" wines, according to the hedonic tests. Sensorial characteristics of $C$. floricula-like R-107 were superior to $C$. sergipensis $\mathrm{R}-101$.

The percentage of acceptance and refusal (Table 4) for the appearance and the aroma of the beverages scored between 20 and $63.33 \%$. Considering all the aspects, the beverage produced by $C$. floricolalike R-107 had the highest acceptance percentage for the parameters $(50,63.33$ and $80 \%$ for appearance, aroma and taste, respectively) and lowest refusal for aroma and taste $(0 \%)$ whereas $C$. 
sergipensis R-101 and Klockera japonica R-48 showed the lowest $\%$ of acceptance for appearance and highest percentage of refusal for the taste.

Table 3 - Average scores of "umbu" wine according to analysis of hedonic scale of nine points answered by 30 not trained tasters.

\begin{tabular}{lccccccccc}
\hline & \multicolumn{10}{c}{ Average of scores } \\
\hline \multicolumn{1}{c}{ ATTRIBUTES } & R-101 & $\mathbf{R - 9 4}$ & $\mathbf{R - 0 3}$ & $\mathbf{R - 1 0 0}$ & $\mathbf{R - 1 3 3}$ & $\mathbf{R - 1 0 9}$ & $\mathbf{R - 4 8}$ & $\mathbf{R}-279$ & $\mathbf{R}-107$ \\
\hline Appearance & $5.4 \mathrm{bc}$ & $5.6 \mathrm{abc}$ & $5.1 \mathrm{c}$ & $5.2 \mathrm{c}$ & $5.7 \mathrm{abc}$ & $6.2 \mathrm{ab}$ & $5.8 \mathrm{abc}$ & $6.6 \mathrm{a}$ & $6.3 \mathrm{ab}$ \\
Aroma & $6.2 \mathrm{ab}$ & $5.4 \mathrm{~b}$ & $5.6 \mathrm{~b}$ & $5.5 \mathrm{~b}$ & $6.2 \mathrm{ab}$ & $5.8 \mathrm{~b}$ & $5.8 \mathrm{ab}$ & $5.9 \mathrm{ab}$ & $6.8 \mathrm{a}$ \\
Taste & $5.8 \mathrm{~cd}$ & $6.5 \mathrm{abc}$ & $5.5 \mathrm{~d}$ & $6.1 \mathrm{bcd}$ & $6.7 \mathrm{abc}$ & $6.2 \mathrm{bcd}$ & $5.9 \mathrm{bcd}$ & $6.8 \mathrm{ab}$ & $7.5 \mathrm{a}$ \\
\hline
\end{tabular}

Average followed by the same lower case letter in the column did not differ (Tukey's test; $\alpha=0.05$ )

Table 4 - Percentage of acceptance and refusal of "umbu" wine according to analysis of hedonic scale of 9 points answered by 30 not trained tasters.

\begin{tabular}{lccccccccc}
\hline & & \multicolumn{10}{c}{ \% of acceptance scores between 7 and 9 } \\
\hline \multicolumn{1}{c}{ ATTRIBUTES } & R-101 & R-94 & R-03 & R-100 & R-133 & R-109 & R-48 & R-279 & R-107 \\
\hline Appearance & 33.33 & 40.00 & 36.67 & 20.00 & 36.67 & 40.00 & 33.33 & 53.33 & 50.00 \\
Aroma & 46.67 & 33.33 & 30.00 & 40.00 & 46.67 & 36.67 & 43.33 & 36.67 & 63.33 \\
Taste & 46.67 & 60.00 & 33.33 & 46.67 & 56.67 & 36.67 & 46.67 & 60.00 & 80.00 \\
\hline \multicolumn{1}{c}{ ATTRIBUTES } & R-101 & R-94 & R-03 & R-100 & R-133 & R-109 & R-48 & R-279 & R-107 \\
\hline Appearance & 16.67 & 20.00 & 26.67 & 16.67 & 13.33 & 6.67 & 13.33 & 0.00 & 10.00 \\
Aroma & 6.67 & 20.00 & 13.33 & 16.67 & 13.33 & 20.00 & 6.67 & 20.00 & 0.00 \\
Taste & 23.33 & 13.33 & 20.00 & 13.33 & 3.33 & 6.67 & 13.33 & 6.67 & 0.00 \\
\hline
\end{tabular}

\section{CONCLUSIONS}

The fruits from the "umbu" tree (Spondias tuberosa) presented a diverse yeast community dominated by ascomycetous species in accordance with the literature on yeast habitats, and included which the recently described $C$. sergipensis, $C$. spandovensis and $C$. sorbosivorans as the prevalent ones. The yeast community showed a predominance of fermentative species (92.6\%); all the strains tested were able to produce wines with acceptable physical, chemical and sensorial characteristics, when compared with grape wine.

C. floricola-like R-107 was able to produce "umbu" wine statistically superior to the other strains. Was concluded that yeast associated with "umbu" and other for the fermentative process and that beverages production could be an alternative use for these fruits and an input in the local economy.

\section{RESUMO}

As leveduras são essenciais na fabricação de bebidas alcoólicas devido a sua alta capacidade de fermentação. Dessa forma, o objetivo deste trabalho foi selecionar linhagens de leveduras fermentadoras e testá-las na produção de vinho semi-artesanal. Os frutos foram coletados em Nossa Senhora da Glória - SE, Brasil. A polpa foi diluída e alíquotas foram inoculadas em placas contendo YMA. Após essa etapa foi realizadas a seleção, purificação e identificação dos morfotipos. As leveduras foram posteriormente submetidas ao teste de fermentação, excetuando-se aquelas relacionadas a processos patológicos, As leveduras testadas produziram vinhos com teor alcoólico que os caracterizaram entre seco e suave, sabor e aparência agradáveis, translúcidos, e cor intermediária entre o verde e o amarelo claro. 


\section{REFERENCES}

Brannon, J.M; Pollit, R.J. (1935), Presence of yeasts in fruit juices that are sold for beverages. Milk. Dealer, 35, 35-39.

Cook, A.H. (1958), The chemistry and biology of yeasts. New York.

Dorneles, D., Machado, I. M. P., Chociai, M. B. et al. (2005), Influence of the use of selected and nonselected yeasts in red wine production. Braz. Arch. Biol. Technol., 48 (5), 747-751.

Furlanetto, S.M.P; Paula, C.R; Gambale, W; Nascimento, D. (1982), Ocorrência de bolores e leveduras em sucos de laranja ao natural. Rev. Microbiol., 13, 31-34.

Hagler. A.N.; Mendonça-Hagler, L.C.; Rosa, C.A.; Morais, P.B. (1995), Yeasts an example of microbial diversity In: Esteves, F.S. (Ed.), Brazilian ecosystems. Oecologia Brasiliensis: Estrutura, Funcionamento e Manejo de Ecossistemas Brasileiros. 1, 225-244.

Ivo, M.I. (1982), Leveduras do abacaxi. Dissertação de mestrado, Escola Paulista de Medicina, São Paulo.

Jay, J.N. (1970), Modern Food Microbiology. New York, van Nostrand Reinbold.

Magalhães, O.M.C; Queiroz, L.A. (1991), Leveduras isoladas de diversos tipos de alimentos. Boletín Micológico, 6 (1,2), 49-54.

Martins, C.V. B.; Horh, J.; Pizzirani-Kleiner, A.A. (1998), Fusão de Protoplastos de Saccharomyces cerevisiae Avaliada por Floculação e Produção de H2S, Revista Scientia Agrícola, (Piracicaba), 55 (1).

Madigan, M.T., Martinko, J.M., Parker, J. (2004), Microbiologia de Brok. Prince Hall, p.466-467.

Morais, P.B.; Lachance, M.A.; Rosa, C.A. (2005), Saturnispora hagleri sp. nov., a yeast species isolated from Drosophila flies in Atlantic Rain Forest in Brazil. International journal of systematic and evolutionary microbiology, 55, 1-5.

Morais, P.B.; Rosa, C.A.; Meyer, S.A.; MendonçaHagler, L.C.; Hagler, A.N. (1995), Candida Amapae, A New Amino Acid-Requiring Yeast From The Amazonian Fruit Parahancornia amapa. Journal of IndustrialMicrobiology, 14 (6), 531-535.

Kurtzman, C.P., Fell, J. (1998), The Yeasts - a taxonomic study.4th. ed. Elsevier Science Pub. B.V. Amsterdam the Netherlands.

Owama, C.I.; Saunders, J.R. (1990), Physiological variants of Saccharomyces cerevisiae and Kloeckera apiculata from palm wine and cashew juice. Journal of Applied Bacteriology, 68, 491-494.

Pelczar, M. J.; Reid, R.; Chan, E.C.S.; (1980), Microbiologia I, Tradutor Manuel Adolfo May Pereira; revisora técnica Maris Regina S. Borges. McGraw- Hill do Brasil, São Paulo.

Phaff, H.J. (1991), Specific habitats of yeasts and their isolation. USFCC Newsletter, 18(4), 11-12.
Pimentel, M.R.C.; Antonini, Y; Martins, R.P.; Lachance, M.A.; Rosa, C.A. (2005), Candida riodocensis and Candida cellae, two new yeast species from the Starmerella clade associated with solitary bees in the Atlantic Rain Forest of Brazil. FEMS Yeast Research, 5(9), 875-879.

Rosa, C.A.; Lachance, M.A. (1998). The Yeast Genus Starmerella Gen. Nov. and Starmerella bombicola Comb. Nov., The Teleomorph of Candida bombicola. International journal of systematic and bacteriology, 48(4), 1413-1417.

Rosa, C.A.; Viana, E.M.; Martins, R.P.; Antonine, Y.; Lachance, M.A. (1999a), Candida batistae, A New Yeast Species Associated With Solitary Digger Nesting Bees In Brazil. Mycologia, 91(3), 428-433.

Rosa, C.A.; Lachance, M.A.; Starmer, W.T.; Barker, J. S. F.; Bowles, J. M.; Schlag-Edler, B. (1999b). Kodamaea nitidulidarum, Candida restingae And Kodamaea anthophila, Three New Related Yeast Species From Ephemeral Flowers. International journal of systematic and bacteriology, 49(1), 309318.

Ruivo, C.C.C.; Lachance, M.A.; Rosa, C.A.; Marini, M.M.; Pagnocca, F.C. (2005) Candida bromeliacearum sp. nov. and Candida ubatubensis sp. nov., two yeast species isolated from the water tanks of Canistropsis seidelii (Bromeliaceae). International journal of systematic and evolutionary microbiology, 55, 1-5.

Santos, E.A.; Oliveira, R.B.; Mendonça-Hagler, L.C.; Hagler, A.N.(1996), Yeasts associated with flowers and fruits from a semi-arid region of Northern Brazil. Rev. Microbiol., 27(1), 33-40.

Silva, F. de A.S.; Azevedo, C.A.V. de. (2002), Versão do programa computacional ASSISTAT para o sistema operacional Windows. Revista Brasileira de Produtos Agroindustriais, 4(1), 71-78.

Silva, F.A.S. (1996), The ASSISTAT Software: statistical assistance. In: International conference on computers in agriculture, 6, Cancun, Anais Cancun: American Society of Agricultural Engineers, 294298.

Teixeira, E.; Meinert, E.M.; Barbetta, P.A. (1987), Análise Sensorial de Alimentos. Série Didática. Florianópolis: Editora UFSC, 18 -102.

Trindade, R.C.; Resende, M.A.; Barreto, E.G.S.; Mendes, T.C.; Rosa, C.A. (1999), Identification of yeasts isolated from processed and frozen cocoa (Theobroma cacao) pulp for wine production. Brazilian Archives of Biology and Technology, 42(3), 349-353.

Trindade, R. C.; Resende, M. A.; Silva, C. M.; Rosa, C. A. (2002), Yeasts Associated With Fresh and Frozen Pulps of Brazilian Tropical Fuits. Systematic and Applied Microbiology, 25, 294-300. 
Trindade, R.C.; Resende, M.A.; Pimenta, R.S.; Lachance, A.M.; Rosa, C.A. (2004), Candida sergipensis a new asexual yeast species isolated from frozen pulps of tropical fruits. Antonie van Leewenhoek, 86, 27-32.

Yarrow, D. (1998), Methods for isolation, maintenance and identification yeasts. In-Kurtzman, C.P., Fell, J. (editors): The Yeasts - a taxonomic study. 4th. ed. Elsevier Science Pub. B.V. Amsterdam the Netherlands. 